\title{
Phenotypic Characterization of Indigenous Chicken of Belagaum Division of Karnataka State, India
}

\author{
B. G. Veeranna Gowda*, Jayanaik, C. S. Nagaraja, M. Veeregowda, \\ T. N. Krishnamurthy, R. Jayashree, A. M. Kotresh, Mahadevappa D. Gouri \\ and D. M. Basavarajaiah
}

Veterinary College, Shivamogga, Karnataka Veterinary, Animal and Fisheries Sciences University, Bidar, Karnataka, India -577204

*Corresponding author

\begin{abstract}
A B S T R A C T
The study was undertaken to characterize the indigenous chicken of Belagaum division of Karnataka State, based on some phenotypic traits. The study included two parts I. Survey study and II. Evaluation under farm conditions. In the survey study a total of eight hundred and ten birds (810), 270 males and 540 females, mature indigenous chicken were randomly sampled from the study area and in the evaluation under farm conditions a total of one hundred and sixty birds (160), 24 males and 136 females from each district were selected for morphological characterization. The study covered three districts (Bijapur, Belagaum and Dharawad). The parameters included feather morphology, feather distribution, plumage colour, primary plumage pattern, secondary plumage pattern, skin colour, shank colour, ear lobe colour, comb type and colour and eye colour as per NBAGR proforma. The most predominant feather type, plumage colour, skin colour, shank colour, comb type, ear lobe colour were normal feather (94.44 \%), brown plumage (29.26\%), yellow skin $(95.45 \%)$, yellow shank $(88.69 \%)$, single comb $(73.42 \%)$, brown eye colour $(56.10 \%)$ and red ear lobe $(100 \%)$ in field conditions and in farm conditions it was normal feather $(92.15 \%)$, brown plumage $(34.44 \%)$, yellow skin $(93.87 \%)$, yellow shank $(87.37 \%)$, single comb $(83.28 \%)$, brown eye colour $(57.55 \%)$ and red ear lobe $(100 \%)$ .The study revealed that most of the parameters measured revealed distinctive variations among the birds of three districts of Belagaum division, providing the basis for further characterization of indigenous chicken; therefore further study can be concentrated towards selection for qualitative traits of interest and conservation of these breeds for future poultry development.
\end{abstract}

\section{Keywords}

Characterization, Indigenous chicken, Morphological characters

\section{Article Info}

Accepted:

10 March 2020

Available Online:

10 April 2020

\section{Introduction}

India is very rich in biodiversity and almost all the animal species are available in India with a large variability within species. India is one of the richest poultry genetic resource countries in the world having 19 indigenous breeds and various subtypes among the 72 breeds found in Asia. The indigenous chicken is a store house of genetic diversity along 
with a number of genomes and major genes of tropical relevance. India and neighbouring countries are considered to be the native tract of Red Jungle Fowl (Gallus gallus) from which the present day domestic birds have been descended. Native chicken production is vital in the livelihood of many house- holds in the country, especially the resources for poor rural farmers providing nutrition for the family (good source of protein), a small cash flow reserve for the need of the family and in some areas contributes to religious ceremonies and recreation (Emuron et al., 2010 and Roberts, 1995).

Rural poultry production constitutes vital component of agricultural economy in India. The organized sector of poultry industry is contributing nearly $67 \%$ of the total output and the rest $33 \%$ in the unorganized sector. The Eastern and Southern region of India contributes around 34.26 per cent and 32.74 per cent respectively. In unorganized sector poultry are reared in free range extensive system with very little input in the form of grain or farm by-products, birds have to scavenge limited amount of feed resource. The productive output of these birds are very low (60-70 eggs per bird per annum; $2.0 \mathrm{~kg}$. and $1.5 \mathrm{~kg}$. body weight per bird in males and females, respectively).The eggs and the meat of birds reared in the family poultry production fetches premium price due to high consumer preference even in the urban sector where plenty of eggs and poultry meat from commercial units are available.

Moreover, still more than $50 \%$ population of poultry in India comprises nondescript / deshi birds. Due to this reason, the per capita availability of eggs and meat is too low as compared to recommended allowance, particularly in rural areas. The indigenous chickens represent valuable resources for livestock development especially in the rural poor's, this is because of their extensive genetic diversity which allows for rearing of poultry under varied environmental conditions (Ajayi, 2010). The knowledge on variation in quantitative and qualitative traits in indigenous chicken and their effects on the performance of the birds can be of tremendous help to provide information for breeding strategies for genetic improvement programmes. The population of most of the native breeds of poultry is decreasing very fast and some of them are in danger of extinction. The native breeds had late sexual maturity, poor egg production, slow growth, broodiness, smaller egg and body size. Native breeds are gold mines of genomes and major genes for improvement of high yielding exotic germplasm for tropical adaptability and disease resistance.

Conservation of these breeds will act as source of variation for future poultry improvement. In addition to this, the native germplasm have great utility for backyard poultry production in India. Systematic studies on morphological characters and the economic traits of indigenous chicken in Karnataka have been studied in Mysore and Bangalore divisions. Hence, study was undertaken in indigenous chicken of Belgaum division of Karnataka, India and their production potential under farm condition. This study is therefore aimed at identifying and providing comparative information on the variations that exist in quantitative and qualitative traits among the indigenous chicken in Belagaum division of Karnataka State.

\section{Materials and Methods}

The present study was carried out to characterize and classify the Indigenous chicken pertaining to three districts of Belagaum division of Karnataka state, India based on the morphological features and to evaluate production performance under farm 
conditions. The study included two parts I. Survey study and II. Evaluation under farm conditions.

The study was carried out in the Veterinary College Shivamogga and Bangalore with an objective to study the production performance of Indigenous chicken under farm conditions. The hatching eggs from twenty villages in each taluka were procured daily for a period of seven days, coded district wise, transported and incubated in the standard forced draft incubator at the college hatchery, Shivamogga. A total of 1979 chicks were wing banded district wise and individually weighed to the accuracy of $1 \mathrm{gm}$ and housed in brooder cum grower house under deep litter system. The standard rearing practices were followed. During the chick stage from 0 to 8 weeks Ad libitum feeding was practiced (diet was formulated as per BIS). During Grower stage from 9 to 18 weeks of age grower diet was fed at the rate of 80 gm per bird. During the layer stage from 19 to 52 weeks of age breeder ration was provided at the rate of 100 gm per bird. The birds were reared up to 52 weeks of age under farm conditions. Data collected were subjected to simple descriptive analysis using SPSS statistical package.

\section{Results and Discussion}

Table 1 revealed qualitative traits distribution among the indigenous chickens in the study area both under field conditions and farm conditions. The reports showed two types of feather morphology (normal feather morphology and frizzled feather morphology). In the present study, under field conditions it was normal feather $(94.43 \%)$ and Frizzle $(5.55 \%)$ and in farm conditions normal feather $(92.15 \%)$ and frizzle $(7.84 \%)$. Feather distribution observed under field conditions was normal $(79.53 \%)$ and naked neck $(20.45 \%)$ and in field conditions it was normal $(90.75 \%)$ and naked neck $(9.18 \%)$.
Results are in agreement with Ajayi and Agaviezor (2009) who observed three feather types' normal $(91.80 \%)$, frizzle $(5.2 \%)$ and naked neck $(3.0 \%)$ in native chicken of Nigeria. Rotimi et al., (2016) reported in indigenous chicken of Nigeria as normal feather $(88.49 \%)$, frizzled feather $(5.31 \%)$ and naked neck $(6.20 \%)$. Both in field condition and in farm condition, Rajakumar (2013) in the indigenous chicken of Bangalore division of Karnataka and Gopinath (2013) in indigenous chicken of Mysore division of Karnataka reported that feather morphology was $(100 \%)$ normal feather.

Under field condition Rajakumar (2013) reported percentage of feather distribution in the indigenous chicken of Bangalore division of Karnataka as normal (96.75\%), naked neck $(2.08 \%)$ and feathered shank and feet $(1.15 \%)$ and in farm condition it was normal (96.97\%), naked neck $(2.73 \%)$ and feathered shank and feet $(0.28 \%)$. Under field condition Gopinath (2013) reported that in the indigenous chicken of Mysore division of Karnataka the feather distribution was normal $(95.03 \%)$ and naked neck $(4.95 \%)$ and in farm condition it was normal $(93.27 \%)$ and naked neck $(6.71 \%)$. Nigussie Dana et al., (2010) documented normal $(81.4 \%)$ and silky feathered (18.6\%) in Native birds of Ethiopia. Sonaiya and Olori (1990) opined that frizzled and naked neck chickens as ugly and irritating and that naked neck chickens are to be raised only by old people and for occult purposes.

Six plumage colour types (white, blue, black, red, brown and multi -colour) were observed. In the present study, under field conditions it was white $(4.25 \%)$, blue $(2.50 \%)$, black (26.85\%), red (19.26\%), brown $(29.26 \%)$ and multi-colour $(17.85 \%)$ and in farm conditions it was white $(3.92 \%)$, blue $(1.18 \%)$, black $(17.07 \%)$, red $(23.44 \%)$, brown $(34.43 \%)$ and multi-colour (19.93\%).Under field conditions, Rajakumar (2013) reported in indigenous 
chicken of Bangalore division as white $(3.83 \%)$, blue $(4.25 \%)$, black $(24.06 \%)$, red $(14.54 \%)$, brown (31.48\%) and multi-colour $(21.30 \%)$ and in farm conditions it was white $(5.33 \%)$, blue $(1.08 \%)$, black $(26.51 \%)$, red $(19.65 \%)$, brown $(29.06 \%)$ and multi-colour (18.35\%).

Under field conditions Gopinath (2013) reported in Mysore division as white (9.97 $\%)$, blue $(0.85 \%)$, black $(15.07 \%)$, red (20.34\%), brown (18.04\%), gold (7.24\%) and multi-colour $(28.44 \%)$ and in farm conditions it was white $(3.88 \%)$, blue $(0.41 \%)$, black (20.89\%), red (18.59\%), brown $(25.80 \%)$, gold $(4.45 \%)$ and multi-colour $(25.93 \%)$.

These observations are comparable with that of Singh and Singh (2004), Tantia et al., (2005b), Vijh et al., (2005b), Tantia et al., (2006a) and Nigussie Dana et al., (2010) in different breeds of indigenous chicken. Rotimi et al., (2016) reported in native chicken of Nigeria as complete white (12.89 $\%)$, complete brown (29.01\%), complete black (10.05\%), and brown with spotted black (15.55\%), black with spotted white $(12.71 \%)$ and white with spotted black (19.79 $\%)$. Duguma (2006) reported very diverse plumage coloration in indigenous chicken of Ethiopia and he concluded that diversity in plumage colour is a feature for camouflaging, adaptability and survival.

Seven primary plumage patterns (solid, dull, stripped, patchy, spotted, barred and mottled) were observed. In the present study, under field conditions it was solid (33.42 \%), dull (24.35\%), stripped $(4.16 \%)$, patchy $(4.25 \%)$, spotted $(6.66 \%)$, barred $(10.37 \%)$ and mottled (16.76\%) and in farm conditions it was solid (49.01\%), dull (30.60\%), stripped (5.71\%), patchy $(8.20 \%)$, spotted $(3.38 \%)$, barred $(8.28 \%)$ and mottled $(8.61 \%)$. The results of the present study are in agreement with Rajakumar, (2013) who reported in field conditions in indigenous chicken of Bangalore division as solid (35.50\%), dull $(23.10 \%)$, stripped $(4.18 \%)$, patchy (6.03 $\%)$, spotted $(7.59 \%)$, barred $(3.87 \%)$ and mottled $(19.7 \%)$ and in farm conditions it was solid (47. $1 \%)$, dull (18.64\%), stripped (4. $64 \%)$, patchy (15.78\%), spotted (2.49\%), barred $(4.81 \%)$ and mottled $(6.43 \%)$.

Under field conditions, Gopinath (2013) reported in indigenous chicken of Mysore division as solid (45.78 \%), dull (8.96\%), stripped (18.46\%), patchy (19.18\%), spotted $(2.39 \%)$, barred $(3.0 \%)$ and mottled $(2.17 \%)$ and in farm conditions it was solid (47.10\%), dull (14.35\%), stripped (4.68\%), patchy $(22.76 \%)$, spotted $(1.72 \%)$, barred $(7.06 \%)$ and mottled $(4.21 \%)$. These observations are on par with the reports of Tantia et al., (2005b), Vij et al., (2005), Tantia et al., (2006a) and Nigussie et al., (2010).

Seven secondary plumage patterns (selfwhite, self-black, self-blue, self-red, barred, lasing and mottled) were observed. In the present study, under field conditions it wasself-white $(4.81 \%)$ self-black $(24.17 \%)$, self-blue $(3.05 \%)$, self-red $(37.03 \%)$, barred $(6.29 \%)$, lasing $(0.00 \%)$ and mottled $(24.62 \%)$ and in farm conditions it was selfwhite $(3.30 \%)$ self-black $(23.03 \%)$, self-blue $(2.11 \%)$, self-red $(41.98 \%)$, barred $(4.12 \%)$, lasing (3.95\%) and mottled (21.44\%).

Under field conditions, Rajakumar (2013) reported in indigenous chicken of Bangalore division as self-white $(3.83 \%)$ self-black $(21.95 \%)$, self-blue $(4.25 \%)$, self-red $(33.77$ $\%)$, barred $(3.67 \%)$, lasing $(6.31 \%)$ and mottled $(26.58 \%)$ and in farm conditions it was self-white $(3.42 \%)$ self-black $(21.84 \%)$, self-blue $(1.20 \%)$, self-red $(37.83 \%)$, barred $(3.88 \%)$, lasing (7.67\%) and mottled $(24.13 \%)$. Under field conditions, Gopinath (2013) reported that in indigenous chicken of Mysore division of Karnataka as self-white 
(12.83\%), self-black (19.69 \%), self-blue $(1.87 \%)$, self-red (37.57\%), barred (3.34\%), lasing (20.38\%)and mottled (4.27\%) and in farm conditions it was self-white $(5.65 \%)$, self-black $(19.78 \%)$, self-blue $(0.62 \%)$, selfred $(44.55 \%)$, barred $(6.90 \%)$, lasing $(9.22$ $\%$ )and mottled (13.24 \%).

Two types of skin colours (yellow and white) were observed. Under field conditions it was Yellow (95.45\%) and white $(4.53 \%)$. In the present study, under farm conditions it was yellow (93.86\%) and white (6.12\%).Under field conditions, Rajakumar (2013) reported in indigenous chicken of Bangalore division as yellow (97.6\%) and white $(2.39 \%)$ and in farm conditions it was yellow $(91.06 \%)$ and white $(8.93 \%)$.

Under field conditions, Gopinath (2013) reported in Mysore division as yellow $(90.04 \%)$ and white $(9.95 \%)$ and in farm conditions it was yellow $(83.11 \%)$ and white $(16.87 \%)$. Pigmentation of non- feathered tissue (skin and shank) involves the carotenoids and melanin's which are responsible for yellow and black colour respectively.

Four types of shank colours (yellow, white, black and green) were observed. In the present study, under field conditions it was yellow (88.69\%), white (2.95\%), black $(6.29 \%)$ and green (2.03) and in farm conditions it was yellow $(87.37 \%)$, white $(2.81 \%)$, black $(7.67 \%)$ and green $(2.11 \%)$. Under field conditions, Rajakumar (2013) reported in Bangalore division as yellow (93.08\%), white $(2.3 \%)$, black $(3.65 \%)$ and green $(0.75 \%)$ and in farm conditions it was yellow $(85.80 \%)$, white $(6.64 \%)$, black $(6.52$ $\%)$ and green $(1.17 \%)$. Under field conditions, Gopinath (2013) reported in Mysore division as yellow (77.97\%), white $(7.03 \%)$, black $(10.89 \%)$ and green $(3.98 \%)$ and in farm conditions it was yellow (85.39
$\%)$, white $(4.44 \%)$, black $(8.76 \%)$ and green (1.38\%). Rotimi et al., (2016) reported in native chicken of Nigeria as yellow (27.23\%), white $(41.16 \%)$ and black $(31.61 \%)$. Egahi et al., (2010) reported black $(42.22 \%)$ as highest in native chickens of Makurdi. The results of the study are in agreement with Tantia et al., (2005b), Vij et al., (2006a), Tantia et al., (2006a) and Vij et al., (2006b). Vij et al., (2005b), Vijh et al., (2005b) and Kumar and Kumar (2007) documented that majority of the birds had yellow coloured shank.

Three types of comb (single comb, pea comb and rose comb) were observed. In the present study, under farm conditions it was single comb $(73.42 \%)$, pea comb $(22.12 \%)$ and rose comb $(4.44 \%)$ and in farm conditions it was Single comb (83.28\%), pea comb (14.21\%) and rose comb (2.48\%). Under field conditions, Rajakumar (2013) reported in Bangalore division as single comb (46.23\%), pea comb $(50.61 \%)$ and rose comb $(3.15 \%)$ and in farm conditions it was single comb $(58.00 \%)$, pea comb $(41.78 \%)$ and rose comb $(0.20 \%)$.

Under field conditions, Gopinath (2013) reported in Mysore division as Single comb $(97.61 \%)$ and pea comb $(2.37 \%)$ and in farm conditions it was Single comb (94.93\%), pea comb (4.67\%) and rose comb (0.38\%). Rotimi et al., (2016) reported in native chicken of Nigeria as single comb $(88.49 \%)$, pea comb (3.90\%), rose comb (7.03\%), buttercup $(0.32 \%)$ and cushion comb $(0.26 \%)$. As per the literature, indigenous chicken populations had predominantly single comb along with pea and rose comb (Nthimo, 2004; Vij et al., 2005; Tantia et al., 2005a; Vijh et al., 2005b). In the present study red coloured comb (100\%) were noticed. Under field conditions, Rajakumar (2013) in Bangalore division reported $100 \%$ red coloured comb and in farm conditions it was Red coloured comb (98.95\%) and black coloured comb 
$(1.03 \%)$. Both in field conditions and in farm conditions, Gopinath (2013) in Mysore division reported Red coloured comb (100\%). Almost all the Indian breeds have red coloured combs (Vijh et al., 2005a; Tantia et al., 2005a; Vijh et al., 2005b; Tantia et al., 2005b; Tantia et al., 2006a; Vij et al., 2006a) except Kadakanath breed which has purple coloured comb (Mohapatra and panda,1981).

Two types of ear lobe colour (red and white) were observed. In the present study, under field conditions it was red ear lobe $(99.62 \%)$ and white $(0.37 \%)$ and in farm conditions it was red ear lobe $(100 \%)$ and white ear lobe $(0.00 \%)$. Under field conditions, Rajakumar (2013) reported in Bangalore division as Red ear lobe $(99.87 \%)$ and white ear lobe $(0.25 \%)$ and in farm conditions it was red ear lobe $(99.87 \%)$ and white ear lobe $(0.25 \%)$. Both in field conditions and in farm conditions, Gopinath (2013) reported in Mysore division as Red ear lobe (100\%). Rotimi et al., (2016) reported in native chicken of Nigeria as red ear lobe $(79.37 \%)$ and white ear lobe $(20.63 \%)$.

Three types of eye colour (grey, brown and black) were observed. In the present study, under field conditions it was grey eye colour (37.57\%), brown eye colour $(54.62 \%)$ and black eye colour (7.77\%) and in farm conditions it was grey eye colour $(35.16 \%)$. Brown eye colour $(57.55 \%)$ and black eye colour (7.26\%). Under field conditions, Rajakumar (2013) reported in Bangalore division as grey eye colour (42.19\%), brown eye colour $(49.65 \%)$ and black eye colour $(11.02 \%)$ and in farm conditions it was grey eye colour $(57.53 \%)$, brown eye colour $(41.54 \%)$ and black eye colour $(0.76 \%)$. Under field conditions, Gopinath (2013) reported in Mysore division as grey eye colour $(8.72 \%)$ and brown eye colour $(91.26 \%)$ and in farm conditions it was grey eye colour $(8.69 \%)$ and brown eye colour
(91.29 \%).According to breed descriptor (NBAGR, 2011) the Ghagus breed had red eye colour. The other eye colours reported in the literature are varied shades of brown, black and grey (Nthimo, 2004; Vij et al., 2005; Vijh et al., 2005a; Kumar and Kumar, 2007).

In the present study, under field conditions wattles were present in $41.01 \%$ and absent in $58.97 \%$ of the birds and in farm conditions wattles were present in $50.56 \%$ and absent in $49.42 \%$ of the birds. Majority of wattles were of red colour (100\%). Under field conditions, Rajakumar (2013) reported in Bangalore division as wattles were present in $49.38 \%$ and absent in $50.61 \%$ and in farm conditions wattles were present in $58.45 \%$ and absent in $41.74 \%$. Under field conditions, Gopinath (2013) reported in Mysore division that wattles were present in $93.42 \%$ and absent in $6.57 \%$ and in farm conditions wattles were present in $96.20 \%$ and absent in $3.78 \%$.

As per the breed descriptor (NBAGR, 2011) the Ghagus breed had smaller red wattles. Nicobari birds had pink coloured wattle (Vijh, et al., 2006), while wattles are absent in Danki breeds (Vij, et al., 2005). Rotimi et al., (2016) reported two types of wattle colour in native chicken of Nigeria as white colour (68.02\%) and red wattle colour (31.98\%).

According to Nesheim et al., (1979), the size and colour of the combs and wattles are associated with gonad development and secretion of sex hormones. Large combs and wattles and long legs are important morphological traits that allow better heat dissipation in the tropical hot environment. Nesheim et al., (1979) also noted that these specialized structures makes up about $40 \%$ of the major heat losses, by radiation, convection and conduction of heat produced from body surfaces. 
Table.1 Percentage distribution of the phenotypic parameters among the indigenous chicken of Belagaum division

\begin{tabular}{|c|c|c|c|c|}
\hline SI.No. & Parameters & Distribution & $\begin{array}{c}\text { Field conditions } \\
(\%)\end{array}$ & $\begin{array}{c}\text { Farm } \\
\text { conditions (\%) }\end{array}$ \\
\hline \multirow[t]{3}{*}{1} & \multicolumn{4}{|l|}{ Feather morphology } \\
\hline & & Normal feather & 94.43 & 92.15 \\
\hline & & Frizzled feather & 5.55 & 7.84 \\
\hline \multirow[t]{3}{*}{2} & \multicolumn{4}{|l|}{ Feather distribution } \\
\hline & & Normal & 79.53 & 90.75 \\
\hline & & Naked neck & 20.45 & 9.18 \\
\hline \multirow[t]{7}{*}{3} & \multicolumn{4}{|l|}{ Plumage colour } \\
\hline & & White & 4.25 & 3.92 \\
\hline & & Blue & 2.50 & 1.18 \\
\hline & & Black & 26.85 & 17.07 \\
\hline & & Red & 19.26 & 23.44 \\
\hline & & Brown & 29.26 & 34.43 \\
\hline & & Multicolour & 17.87 & 19.93 \\
\hline \multirow[t]{8}{*}{4} & \multicolumn{4}{|l|}{ Primary plumage pattern } \\
\hline & & Solid & 33.42 & 49.01 \\
\hline & & Dull & 24.35 & 30.60 \\
\hline & & Stripped & 4.16 & 5.71 \\
\hline & & Patchy & 4.25 & 8.20 \\
\hline & & Spotted & 6.66 & 3.38 \\
\hline & & Barred & 10.37 & 8.28 \\
\hline & & Mottled & 16.76 & 8.61 \\
\hline \multirow[t]{8}{*}{5} & \multicolumn{4}{|c|}{ Secondary plumage pattern } \\
\hline & & Self-White & 4.81 & 3.30 \\
\hline & & Self-Black & 24.17 & 23.03 \\
\hline & & Self-Blue & 3.05 & 2.11 \\
\hline & & Self-Red & 37.03 & 41.98 \\
\hline & & Barred & 6.29 & 4.12 \\
\hline & & Lasing & 0.00 & 3.95 \\
\hline & & Mottled & 24.62 & 21.44 \\
\hline \multirow[t]{3}{*}{6} & \multicolumn{4}{|l|}{ Skin colour } \\
\hline & & Yellow & 95.45 & 93.86 \\
\hline & & White & 4.53 & 6.12 \\
\hline \multirow[t]{5}{*}{7} & \multicolumn{4}{|l|}{ Shank colour } \\
\hline & & Yellow & 88.69 & 87.37 \\
\hline & & White & 2.95 & 2.81 \\
\hline & & Black & 6.29 & 7.67 \\
\hline & & Green & 2.03 & 2.11 \\
\hline 8 & \multicolumn{4}{|l|}{ Ear lobe colour } \\
\hline
\end{tabular}




\begin{tabular}{|c|c|c|c|c|}
\hline & & Red & 99.62 & 100.00 \\
\hline & & White & 0.37 & 0.00 \\
\hline \multirow[t]{4}{*}{9} & \multicolumn{4}{|l|}{ Comb type } \\
\hline & & Single & 73.42 & 83.28 \\
\hline & & Pea & 22.12 & 14.21 \\
\hline & & Rose & 4.44 & 2.48 \\
\hline \multirow[t]{3}{*}{10} & \multicolumn{4}{|l|}{ Comb colour } \\
\hline & & Red & 100.00 & 100.00 \\
\hline & & Black & 0.00 & 0.00 \\
\hline \multirow[t]{4}{*}{11} & Eye colour & & & \\
\hline & & Grey & 37.57 & 35.16 \\
\hline & & Brown & 54.62 & 57.55 \\
\hline & & Black & 7.77 & 7.26 \\
\hline \multirow[t]{3}{*}{12} & Wattles & & & \\
\hline & & Present & 41.01 & 50.56 \\
\hline & & Absent & 58.97 & 49.42 \\
\hline
\end{tabular}

Based on the results of the present study on characterization and performance evaluation of indigenous chicken of Belagaum division the following conclusions can be drawn.

The present study reveals phenotypic variability which is affected by both genetic and environmental factors. Considering the hardy nature and productive performance of these chickens they have vast potential for subsequent breeding works.

The indigenous chicken of all the three districts evaluated needs further investigation for molecular characterization and Genetic similarity / divergence with other Indian breeds and efforts must be taken to conserve these germplasm.

\section{References}

Ajayi, F.O (2010). Nigerian indigenous chicken: A value genetic resources for meat and egg production. Asian journal of poultry science. 4:164-172.

Ajayi, F.O and Agaviezor, B.O. (2009). Phenotypic characteristics of indigenous chicken in selected local Government areas in
Bayelsa State, Nigeria International Poultry Summit Feb. 22-26, Abeokuta. Pp. 75-78.

Duguma, R. (2006). Phenotypic characterization of some indigenous chicken ecotypes of Ethiopia. Livestock Rese. Rural Dev., 18:2006.

Egahi, J.O., Dim, N.I, Momoh, O.M. and Gwaza, D.S. (2010). Variations in Qualitative traits in the Nigeria local chicken. International Journal of Poultry Science. 9:978-979.

Emuron N., Magala H., Kuginza D.R., KYAZXE F.B. and Kyyarisuma C.C. (2010). Factors influencing the trade of local chickens. Livestock Research Rural Development. 22(4):http//www.lordorg/irrd22/4.

Gopinath, 2013. Characterization and performance evaluation of indigenous chicken in the Mysore division of Karnataka State, Ph.D. Thesis submitted to KVAFSU, Bidar.

Kumar, S. and Kumar, D., 2007. Local Hill Fowl of Uttarakhand State. Department of Genetics and Animal Breeding, College of Veterinary and Animal Sciences, G.B. Pant University of Agriculture and Technology, Pant Nagar, Uttarakhand State, 5p.

Mohapatra, S.C. and Panda, B., 1981. Poultry Genetic Resources, Poultry industry year Book. Pp. 50-58.

NBAGR-National Bureau of Animal Genetic Resources. 2011. Breed Descriptor of 
chicken. Indian J. Anim. Sci., 81(3):31.323.

Negusie Dana, Dessie, T., Liesbeth, H., Waaij, V. and Arendonk, J.A.M., 2010. Morphological features of indigenous chicken population of Ethiopia. Anim. Genetic Resou. 46:11-23.

Nesheim, C.M., Austic, E.R. and Card, E.L. (1979). Poultry production Lea and Febiger Philadelphia $12^{\text {th }}$ Edition; pp: 58-92.

Nthimo, A.M., 2004. The Phenotypic characterization of native Lesotho chickens. Magister Scientiae Agriculturae Thesis, University of the Free State, Bloemfontein.pp. 82.

Rajakumar, 2013.Characterization and performance evaluation of indigenous chicken in the Bangalore division of Karnataka State, Ph.D. Thesis submitted to KVAFSU, Bidar.

Roberts, J.A. (1995). Assessing the scavenging feed resource base for sustainable smallholder poultry development. Proceedings ANRPD workshop, Addis Ababa, Ethiopia.Pp:40-52.

Rotimi E.A., Egahi J.O. and Adeoye A.A. 2016. Phenotypic characterization of indigenous chicken population in Gwer-West, Benue State, Nigeria. World Scientific News 53(3) (2016), 343-353.

Singh. R. and Singh. D.P., 2004. Possibilities of exploitation of indigenous poultry germplasm. Livestock Biodiversity visa-a-vis Resource Exploitation: introspection. Proceedings of national symposium, National Bureau of Animal Genetics and Research, Karnal, pp.21-30.

Sonaiya, E.B. and Olori, V.E. (1990). Village poultry production in South western Nigeria.
In: E.B. Sonaiya, ed. Rural Poultry in Africa: Proc. Of Int. Workshop held in Ile-Ife, Nigeria, November 13-16, pp.243-247.

Tantia, M.S., Ganai, N., Vij, P.K., Vijh, R.K., and Ahlawat S.P.S., 2005a. Chicken Breeds of India Kashmir Favorella. Leaflet 22, National Bureau of Animal Genetic Resources. P.O. Box 129, Karnal. 132001.

Tantia, M.S., Ganai, N., Vij, P.K., Vijh, R.K., and Ahlawat S.P.S., 2005b. Chicken Breeds of India Ghagus. Leaflet 22, National Bureau of Animal Genetic Resources. P.O. Box 129, Karnal. 132001.

Tantia, M.S., Khanna, K., Vij.H.R.K. Vij, P.K., Singh, G. Ahlawat S.P.S., 2006a. Chicken breeds of India -Ankaleshwar. Leaflet 37, National Bureau of Animal Genetic Resources. P. O. Box129, Karnal, 132001.

Vij, P.K., Tantia, M.S., Vijh, R.K. and Ahlawat S.P.S., 2005. Chicken Breeds of India Danki. Leaflet 23, National Bureau of Animal Genetic Resources. P.O. Box 129, Karnal. 132001.

Vijh, R.K., Chataerjee, R.N., Vij, P.K., Tantia, M.S., and Ahlawat S.P.S., 2006. Chicken Breeds of India-Nicobari. Leaflet 36, National Bureau of Animal Genetic Resources. P.O. Box 129, Karnal., 132001.

Vijh, R.K., Roy, T.C., Vij, P.K., Tantia, M.S., and AHLAWAT S.P.S., 2005a. Chicken Breeds of India Miri. Leaflet 2, National Bureau of Animal Genetic Resources. P.O. Box 129, Karnal. 132001.

Vijh, R.K., Vij, P.K., Tantia, M.S., and Ahlawat S.P.S., 2005b. Chicken Breeds of IndiaKalasthi. Leaflet 21, National Bureau of Animal Genetic Resources. P.O. Box 129, Karnal, 132001.

\section{How to cite this article:}

Veeranna Gowda, B. G., Jayanaik, C. S. Nagaraja, M. Veeregowda, T. N. Krishnamurthy, R. Jayashree, A. M. Kotresh, Mahadevappa D. Gouri and Basavarajaiah, D. M. 2020. Phenotypic Characterization of Indigenous Chicken of Belagaum Division of Karnataka State, India. Int.J.Curr.Microbiol.App.Sci. 9(04): 1304-1312. doi: https://doi.org/10.20546/ijcmas.2020.904.154 